DOI: $10.1515 /$ awutp -2015-0105

\title{
ANALYSIS OF METAL CONTENT IN SOIL IN TIMIS COUNTY
}

\author{
N. Stefu* , A. Neculae, L. Turcu and A. Balint
}

Faculty of Physics, West University of Timisoara,Bd. V. Parvan nr. 4, 300223, Timisoara, ROMANIA

\section{Article Info \\ Received: 19.03.2013 \\ Accepted: 30.03.2013}

Keywords: Metal content, Soil, X-ray fluorescence, Timis county

PACS: 78.70.En, 89.60.-k, 1.62.Rt.

\begin{abstract}
The paper reports on the presence of various metals in soil in Timis county. A set of 18 samples were collected from different points of interest. The metal content of the samples was investigated using a handheld XRF Niton XLp 300 GOLDD analyzer. Special attention was paid to the metals with harmful potential to humans. Based on the obtained results, a set of conclusions on the environment's health was drawn.
\end{abstract}

\section{Introduction}

The soil is a natural layer on the top of Earth's surface, having specific properties and functions, developed naturally in a long period of time, but influenced more and more by human activities at present. It is a very complex medium, having an important role in supporting the vegetation, balancing the flow of water, reducing air pollution and recycling the dead organic matter and pollutants. At the same time, it is a limited resource and its improper use in various human activities may result in damaging large areas beyond recovery.

Heavy metals are natural elements in Earth's surface. Some of them play an essential role in the metabolism of living organisms, including the human one. Iron, cobalt, copper, manganese, molybdenum, and zinc are required by humans [1].They get into the organism in small quantities, along with food, water or even air [2]. In larger quantities, though, metals can become toxic [3]. The negative effect of metals on humans can build up, due to their tendency of bioaccumulation, by ingesting contaminated plants or drinking contaminated water. Pollution of soil with heavy metals originates mainly from industrial wastes. Some of these metals, like $\mathrm{Pb}, \mathrm{Cr}, \mathrm{Co}, \mathrm{Ni}$ and $\mathrm{Se}$ are known for their carcinogen effects. They are commonly present in industrial environment [4], but have also been found in the air in the 
vicinity of industrial areas $[2,5]$. Pb reaches the atmosphere by means of exhaust gases, paints or pesticides, and then it enters the soil or water and gets absorbed by plants, mainly in roots. From the atmosphere it can also deposit directly on the leaves of plants [2]. Once inside the organism, it partially accumulates in bones or hair, and partially in liver [6]. Cd has also a strong toxic effect on living organisms. It enters through skin or along with food, and accumulates in tissues, partially bonding to proteins [6]. The content of $\mathrm{Cd}$ and $\mathrm{Pb}$ in the edible part of the fresh root vegetables (carrots, radish, potatoes) or in leafy vegetables (lettuce, parsley, dill) collected in some polluted areas in Romania, exceeded several times the normal concentration, reaching up to 7 times for $\mathrm{Cd}$, or 17 times for $\mathrm{Pb}$ [7]. $\mathrm{Co}$ and $\mathrm{Ni}$ are also used in many human activities, and can alter the health in excessive quantities.

This paper reports on the metal content in soil in Timis county, a region in the western part of Romania.

\section{Samples and method}

\subsection{Sample Locations and Characterization}

A set of 18 soil samples were collected from different locations in Timis county (see figure 1), in urban or rural areas, including various types of soils (see table 1). The soil samples were finely grinded, homogenized and then analyzed.

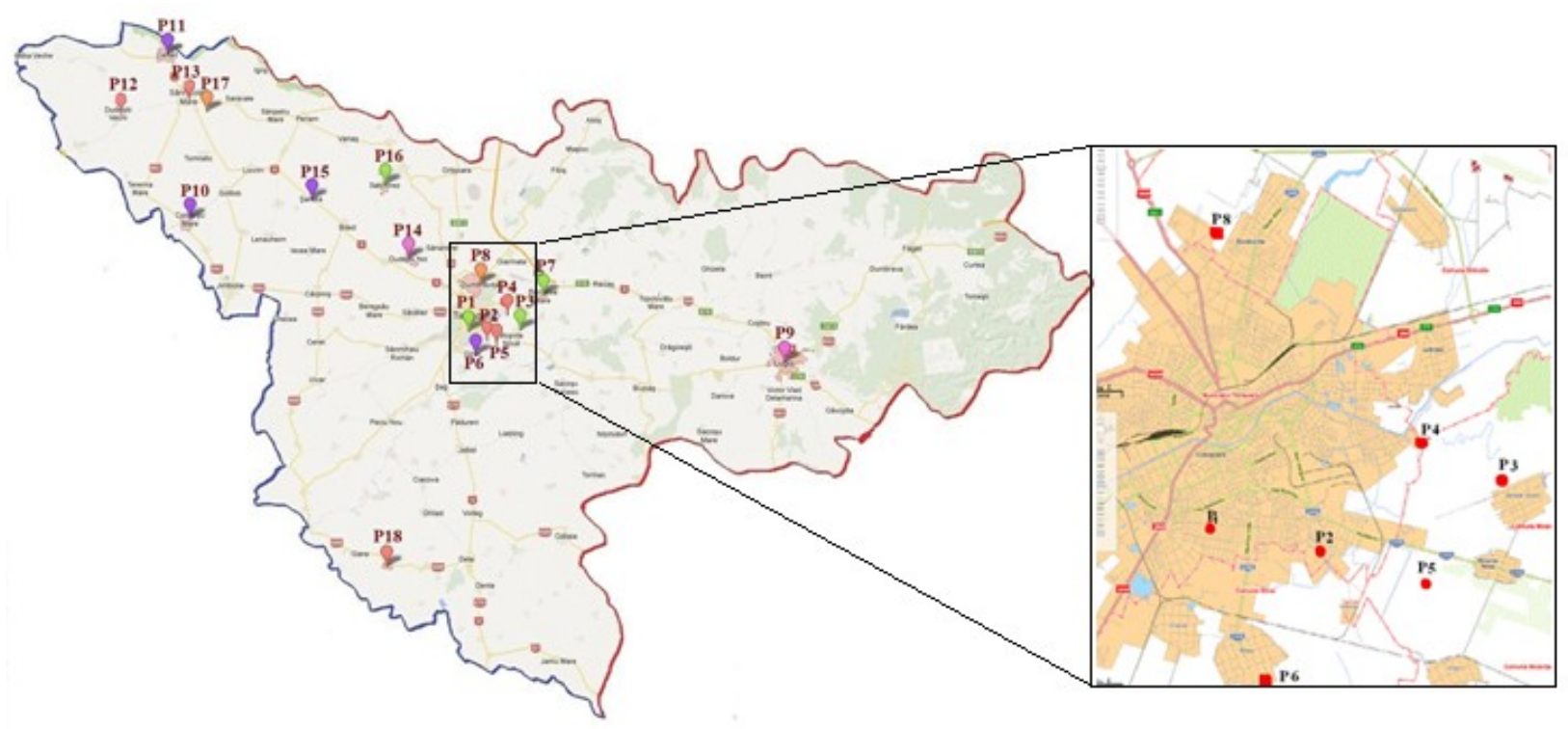

Fig. 1. Location of samples on the map of Timis county. The detail represents the city of Timisoara 
TABLE 1. The sample locations and their geographic coordinates.

\begin{tabular}{|c|c|c|c|}
\hline Samples & Location & Coordinates & Type of soil \\
\hline P1 & Timisoara & $\mathrm{N} 45^{\circ} 43^{\prime} 46.9^{\prime \prime}, \mathrm{E} 21^{\circ} 13^{\prime} 25^{\prime \prime}$ & Sand, fine, gray, medium dense \\
\hline $\mathrm{P} 2$ & $\begin{array}{l}\text { Giroc (Calea } \\
\text { Urseni) }\end{array}$ & $\mathrm{N} 45^{\circ} 43^{\prime} 13.5^{\prime}$, , E $21^{\circ} 16^{\prime} 1.5^{\prime \prime}$ & Sandy clay, plastically consistent \\
\hline P3 & Mosnita Veche & $\begin{array}{l}\text { N } 45^{\circ} 44^{\prime} 21.6^{\prime}, \text {, E } 21^{\circ} 19^{\prime} \\
34.6^{\prime \prime}\end{array}$ & $\begin{array}{l}\text { Sand, fine, gray, medium dense with clay } \\
\text { lenses }\end{array}$ \\
\hline P4 & Ghiroda & $\begin{array}{l}\mathrm{N} 45^{\circ} 45^{\prime} 16.7^{\prime}, \text {, E } 21^{\circ} 18^{\prime} \\
22.8^{\prime \prime}\end{array}$ & $\begin{array}{l}\text { Loam, plastically consistent, with iron } \\
\text { oxides }\end{array}$ \\
\hline P5 & Mosnita Noua & $\begin{array}{l}\mathrm{N} 45^{\circ} 43^{\prime} 02.3^{\prime \prime}, \text { E } 21^{\circ} 17^{\prime} \\
22.2^{\prime \prime}\end{array}$ & $\begin{array}{l}\text { Medium sand, gray, medium dense with } \\
\text { pebbles }\end{array}$ \\
\hline P6 & Giroc (Str. Timis) & $\begin{array}{l}\mathrm{N} 45^{\circ} 41^{\prime} 28.1^{\prime \prime}, \text { E } 21^{\circ} 14^{\prime} \\
33.1^{\prime \prime}\end{array}$ & $\begin{array}{l}\text { Medium sand, brown, medium dense with } \\
\text { pebbles }\end{array}$ \\
\hline P7 & Remetea Mare & $\begin{array}{l}\mathrm{N} 45^{\circ} 47^{\prime} 03.8^{\prime}, \text {, E } 21^{\circ} 23^{\prime} \\
08.2^{\prime \prime}\end{array}$ & $\begin{array}{l}\text { Clay, gray, plastically consistent, with } \mathrm{Fe} \\
\text { oxides and altered carbon concretions }\end{array}$ \\
\hline P8 & Dumbravita & $\mathrm{N} 45^{\circ} 47^{\prime} 43.76^{\prime}$, , E $21^{\circ} 13^{\prime} 38^{\prime \prime}$ & $\begin{array}{l}\text { Clay, brown, plastically stiff, with Fe } \\
\text { oxides and iron-manganese concretions }\end{array}$ \\
\hline P9 & Lugoj & $\begin{array}{l}\mathrm{N} 45^{\circ} 43^{\prime} 03.4^{\prime}, \text {, E } 21^{\circ} 52^{\prime} \\
55.6^{\prime \prime}\end{array}$ & Medium sand, gray, dense \\
\hline P10 & Comlosu Mare & $\mathrm{N} 45^{\circ} 53^{\prime} 49.2^{\prime \prime}$, E $20^{\circ} 36^{\prime} 49.7^{\prime \prime}$ & Sand, brown, medium dense \\
\hline P11 & Cenad & $\begin{array}{l}\mathrm{N} 46^{\circ} 07^{\prime} 44.6^{\prime}, \text {, E } 20^{\circ} 31^{\prime} \\
12.9^{\prime \prime}\end{array}$ & $\begin{array}{l}\text { Sand, medium fine, gray, medium dense, } \\
\text { with rotten vegetal pieces }\end{array}$ \\
\hline P12 & Dudestii Vechi & $\begin{array}{l}\text { N } 46^{\circ} 03^{\prime} 07.8^{\prime}, \text {, E } 20^{\circ} 29^{\prime} \\
14.7^{\prime}\end{array}$ & Sand, fine, gray, medium dense \\
\hline P13 & Sannicolau Mare & $\begin{array}{l}\text { N } 46^{\circ} 00^{\prime} 10.6^{\prime}, \text {, E } 20^{\circ} 33^{\prime} \\
10.8^{\prime \prime}\end{array}$ & Loam clay, plastically consistent \\
\hline P14 & Dudestii Noi & $\begin{array}{l}\mathrm{N} 45^{\circ} 48^{\prime} 59.7^{\prime}, \text {, E } 21^{\circ} 06^{\prime} \\
10.4^{\prime \prime}\end{array}$ & Clay, gray, plastically stiff, with Fe oxides \\
\hline P15 & Uihei (Sandra) & $\begin{array}{l}\mathrm{N} 45^{0} 54^{\prime} 42.2^{\prime \prime}, \text { E } 20^{\circ} 51^{\prime} \\
39.2^{\prime \prime}\end{array}$ & Sand, brown, medium fine, medium dense \\
\hline P16 & Satchinez & $\begin{array}{l}\mathrm{N} 45^{\circ} 56^{\prime} 59^{\prime},, \quad \text { E } 21^{0} 03^{\prime} \\
28.9^{\prime \prime}\end{array}$ & $\begin{array}{l}\text { Silty clay, brown, plastically stiff with } \\
\text { altered carbon concretions }\end{array}$ \\
\hline P17 & Sanpetru Mare & $\begin{array}{l}\mathrm{N} 46^{\circ} 04^{\prime} 13^{\prime \prime}, \quad \text { E } 20^{\circ} 49^{\prime} \\
09.6^{\prime \prime}\end{array}$ & Sand, brown, medium fine, medium dense \\
\hline P18 & Livezile & $\begin{array}{l}\text { N } 46^{\circ} 21^{\prime} 54.6^{\prime}, \text { E } 21^{\circ} 03^{\prime} \\
11.7^{\prime}\end{array}$ & Sand, fine, gray, with Fe oxides \\
\hline
\end{tabular}

\subsection{Measurement Method}

The samples were measured using a handheld Thermo Scientific Niton XL3t GOLDD analyzer. The measurement technique is based on X-ray fluorescence (XRF) which consists on the emission of characteristic "secondary" (or fluorescent) X-rays from a material that has been excited by bombarding with high-energy X-rays. The rate of generation of secondary photons is proportional to the element concentration.

The GOLDD (Geometrically Optimized Large Area Drift Detector) technology permits to identify elemental concentrations from low levels to high level of contaminated soil, onsite, in real time.

The analyzer is equipped with a $50 \mathrm{kV}$ X-ray tube sample excitation system, a highperformance thermoelectrically cooled detector, $80 \mathrm{MHz}$ real-time digital signal processing, 
and dual state-of-the-art embedded processors for computation, data storage, communication, and other functions.

The measurements were performed "ex-situ" in order to have the possibility to carefully prepare the samples. The "matrix effects" are minimized by pressing the soil grains into a pellet for improving the homogeneity of the sample. The measuring time was 10 to 15 second, which assures accurate results. The analyzer provides both the metal concentrations and the specific XRF spectrum for each sample.

\section{Results and disscussions}

\subsection{FRX Spectra}

For each sample a FRX spectrum was obtained, and the concentrations of metals were determined. The XRF spectra of the most and less abundant in Fe samples are presented in figures 2 a) and b), respectively, as examples.

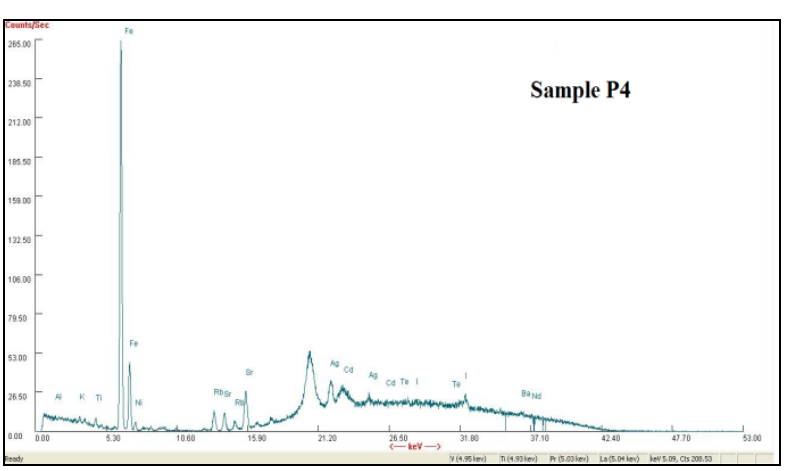

a)

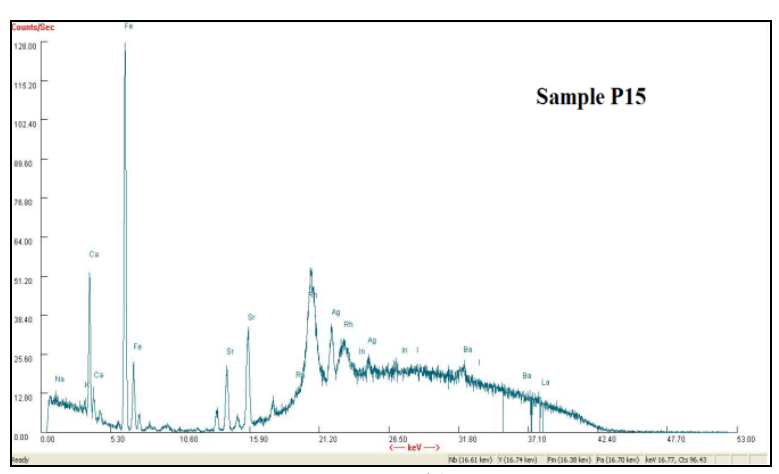

b)

Fig. 2. FRX spectra of the a) most abundant in Fe sample (P4) and b) the less abundant in Fe sample, P15

\subsection{Measurement Results}

The measurement results are presented in Table 2. For emphasizing the significant values, the largest metal concentration, i.e. the highest value on each column, is bolded, and the lowest non zero metal concentration is underlined.

The metal concentrations presented in Table 3 were measured and found to be zero for all samples.

The results show that $\mathrm{Zn}$ is present in all locations in low to normal concentrations; $\mathrm{Pb}$ is generally absent in the investigated samples, excepting sample (P4), which contains $\mathrm{Pb}$ in a concentration 1.3 times the normal value; only two samples present As, both in concentrations approximately 1.5 times the normal value; three samples contain Ni, (P6, P11 and P13) all having concentrations exceeding the normal value 2.4 and 3 times, respectively; 
$\mathrm{Cu}$ is either missing (5 samples) or exceeding the normal value (the other 13 samples), by a factor of as much as 2.5 (sample P3); Mn is generally present, in moderate concentrations, with only two exceptions which exceed the normal concentration (P8 and P13).

For the other investigated metals, there are no normal concentrations indicated by law.

A comparison between urban, suburban and rural sites indicates that samples P4 and P8 from suburbia of Timisoara (the first being also close to the airport) are the champions of the polluted sites, having four maximum values each, for $\mathrm{Rb}, \mathrm{Pb}, \mathrm{Zn}$ and $\mathrm{Cu}(\mathrm{P} 4)$ and $\mathrm{As}, \mathrm{Cu}, \mathrm{Mn}$ and $\mathrm{Bi}(\mathrm{P} 8)$. At the opposite, the most remote rural sites show the smallest metal concentrations in soil: sample P15 with four minimal non zero values and five zeros, and sample P10, with one minimum value and seven zero concentrations.

The contamination/pollution index $(\mathrm{C} / \mathrm{P}$ index $)$ as defined in [9], representing the ratio between the heavy metal content effectively measured in soil by chemical analysis and the reference value A (obtained by calculation for each sample using the formulae of the Dutch system), computed for each sample for $\mathrm{Pb}, \mathrm{Zn}, \mathrm{Cu}$ and $\mathrm{Ni}$ is presented in Table 4. The multiple pollution index is computed as a sum of individual indices. The significance of the values of the $\mathrm{C} / \mathrm{P}$ index is as follows [9]:

- Contamination: very slight $(\mathrm{C} / \mathrm{p}<0.1)$, slight (0.1-0.25), moderate $(0.26-0.50)$, severe (0.51-0.75) and very severe contamination (0.76-1.00)

- Pollution: slight (1.1-2.0), moderate (2.1-4.0), severe (4.1-8.0), very severe (8.1-16.0) and excessive $(>16.0)$.

As far as the C/P index for the four metals is concerned, the most polluted sites are the ones corresponding to samples P6, P11 and P13, while the less polluted are confirmed to be $\mathrm{P} 10$ and P15, as also resulted from Table 2. 
TABLE 2. Metal concentration in samples.

\begin{tabular}{|c|c|c|c|c|c|c|c|c|c|c|c|c|c|c|c|c|}
\hline Sample & Location & Unit & $\mathbf{Z r}$ & $\mathrm{Sr}$ & $\mathbf{R b}$ & Th & $\mathbf{P b}$ & As & Zn & $\mathrm{Cu}$ & $\mathbf{N i}$ & $\mathrm{Fe}$ & Mn & $\mathbf{T i}$ & $\mathbf{N b}$ & $\mathbf{B i}$ \\
\hline $\mathbf{P 1}$ & Timisoara & ppm & 183.75 & 72.88 & 54.26 & 11.7 & 14.32 & 0 & 70.23 & $\underline{24.31}$ & 0 & 27887.67 & 0 & 2557.62 & 13.32 & 11.21 \\
\hline $\mathbf{P 2}$ & Giroc (Calea Urseni) & ppm & 195.86 & 79.5 & 44.51 & 13.38 & 17.76 & 0 & 63.92 & 0 & 0 & 36702.38 & 394.83 & 1532.98 & 13.59 & 11.33 \\
\hline P3 & Mosnita Veche & ppm & 186.13 & 67.92 & 56.23 & 14.47 & 15.19 & 0 & 69.55 & 49.44 & 0 & 30664.42 & 250.53 & 2204.27 & 13.88 & 14.65 \\
\hline P4 & Ghiroda & ppm & 120.69 & 57.64 & 60.38 & 12.45 & 26.09 & 0 & 98.72 & 47.74 & 0 & 30343.60 & 255.29 & 1663.87 & 13.67 & $\underline{9.93}$ \\
\hline P5 & Mosnita Noua & ppm & 209.98 & 63.55 & 42.48 & 12.55 & 0 & 0 & 44.14 & 38.75 & 0 & 20957.29 & 378.07 & 2226.54 & 15.68 & 11.88 \\
\hline P6 & Giroc (Str. Timis) & ppm & 187.84 & 73.69 & 44.1 & 13.68 & 0 & 0 & 51.81 & 0 & 71.56 & 22288.52 & 344.79 & 2726.92 & 16.94 & 0 \\
\hline P7 & Remetea Mare & ppm & 213.37 & 57.1 & 52.94 & 12.2 & 0 & 0 & 57.03 & 32.15 & 0 & 30368.86 & 689.65 & 2368.18 & 12.04 & 0 \\
\hline P8 & Dumbravita & ppm & 208.63 & 58.18 & 51.16 & 16.38 & 0 & 7.78 & 62.83 & 34.76 & 0 & 26662.14 & 1029.19 & 1938.05 & 13 & 14.66 \\
\hline P9 & Lugoj & ppm & 145.03 & 76.91 & 46.33 & 17.33 & 11.06 & 0 & 54.06 & 44.76 & 0 & 26957.70 & 704.53 & 2556.31 & 15.72 & 18 \\
\hline P10 & Comlosu Mare & ppm & 122.62 & 76.31 & $\underline{32.49}$ & 0 & 0 & 0 & 44.74 & 0 & 0 & 20473.25 & 561.34 & 0 & 8.57 & 0 \\
\hline P11 & Cenad & $\mathrm{ppm}$ & 134.41 & 79.9 & $\overline{56.34}$ & 11.35 & 16.79 & 0 & 79.04 & 29.64 & 59.39 & 32608.10 & 877.14 & 2749.69 & 12.78 & 11.63 \\
\hline P12 & Dudestii Vechi & ppm & $\underline{97.56}$ & 76.92 & 41.44 & 6.97 & 0 & 0 & 70.24 & 0 & 0 & 18934.24 & 486.34 & 0 & 6.86 & 0 \\
\hline P13 & Sannicolau Mare & $\mathrm{ppm}$ & 117.33 & 116.92 & 41.33 & 6.36 & 0 & 0 & 58.22 & 34.5 & 59.17 & 21345.71 & 948.26 & 1780.54 & $\underline{6.78}$ & 0 \\
\hline P14 & Dudestii Noi & ppm & 207.89 & 50.68 & 44.36 & 11.71 & 0 & 7.46 & 47.94 & 35.35 & 0 & 23532.07 & $\underline{211.39}$ & 2626.74 & 12.09 & 0 \\
\hline P15 & Uihei & $\mathrm{ppm}$ & 152.26 & 107.9 & 33.65 & $\underline{6.1}$ & 0 & 0 & $\underline{39.82}$ & 0 & 0 & $\underline{14172.93}$ & 393.61 & $\underline{1098.55}$ & 7 & 0 \\
\hline P16 & Satchinez & ppm & 204.33 & $\underline{50.13}$ & 45.88 & $1 \overline{11.66}$ & 0 & 0 & $\overline{47.62}$ & 26.49 & 0 & $\overline{23357.55}$ & 493.35 & 2040.65 & 12.65 & 0 \\
\hline P17 & Sanpetru Mare & ppm & 143.66 & $\overline{83.05}$ & 52.2 & 11.39 & 13.19 & 0 & 78.47 & 46.19 & 0 & 33689.27 & 587.17 & 2033.22 & 13.97 & 0 \\
\hline P18 & Livezile & ppm & 166.56 & 67.33 & 58.2 & 13.73 & 0 & 0 & 49.4 & 27.97 & 0 & 24546.11 & 323.26 & 2346.90 & 12.72 & 14.38 \\
\hline $\begin{array}{l}\text { Normal } \\
\text { value }\end{array}$ & [8] & $\mathrm{g} / \mathrm{kg}$ & & & & & 20 & 5 & 100 & 20 & 20 & & 900 & & & \\
\hline $\begin{array}{l}\text { Alert } \\
\text { Threshold } \\
\text { urban soil }\end{array}$ & [8] & $\mathrm{g} / \mathrm{kg}$ & & & & & 250 & 25 & 700 & 250 & 200 & & 2000 & & & \\
\hline $\begin{array}{l}\text { Alert } \\
\text { Threshold } \\
\text { rural soil } \\
\text { (garden) }\end{array}$ & {$[8]$} & $\mathrm{g} / \mathrm{kg}$ & & & & & 50 & 15 & 300 & 100 & 75 & & 1500 & & & \\
\hline
\end{tabular}

TABLE 3. Metal concentrations measured and found to be zero in all samples

\begin{tabular}{lllllllllll}
\hline Element & U & Se & Hg & Au & Cr & Sb & Sn & Cd & Pd & Ag \\
\hline Concentration $[\mathrm{ppm}]$ & 0 & 0 & 0 & 0 & 0 & 0 & 0 & 0 & 0 & 0 \\
\hline Normal value $[\mathrm{ppm}][8]$ & & 1 & 0.1 & & 30 & & 20 & 1 & & 2 \\
\hline
\end{tabular}


TABLE 4. Contamination/Pollution index for $\mathrm{Pb}, \mathrm{Zn}, \mathrm{Cu}, \mathrm{Ni}$ and multiple pollution for all samples. Abbreviations used in table: S.p. - slight pollution; M.p. - moderate pollution; Sev.p - severe pollution; V. Sev.p - very severe pollution

\begin{tabular}{|c|c|c|c|c|c|c|}
\hline Sample & Location & $\begin{array}{c}\mathrm{C} / \mathrm{P} \text { index } \\
\mathrm{Pb}\end{array}$ & $\begin{array}{c}\mathrm{C} / \mathrm{P} \text { index } \\
\mathrm{Zn}\end{array}$ & $\begin{array}{c}\mathrm{C} / \mathrm{P} \text { index } \\
\mathrm{Cu}\end{array}$ & $\begin{array}{c}\mathrm{C} / \mathrm{P} \text { index } \\
\mathrm{Ni}\end{array}$ & $\begin{array}{c}\text { Multiple } \\
\text { pollution index }\end{array}$ \\
\hline P1 & Timisoara & 0.29 & 1.40 (S. p.) & 1.62 (S. p.) & 0 & 3.31 (M.p) \\
\hline $\mathbf{P 2}$ & Giroc & 0.36 & 1.28 (S. p.) & 0 & 0 & 1.63 (S.p) \\
\hline $\mathbf{P 3}$ & Mosnita Veche & 0.30 & 1.39 (S. p.) & 3.30(M.p.) & 0 & 4.99 (Sev.p) \\
\hline P4 & Ghiroda & 0.52 & 1.97 (S. p.) & 3.18(M.p.) & 0 & 5.68 (Sev.p) \\
\hline P5 & Mosnita Noua & 0 & 0.88 & 2.58(M.p.) & 0 & 3.47 (M.p) \\
\hline P6 & Giroc & 0 & 1.04 (S. p.) & 0 & 7.16 (Sev.p) & 8.19 (V.Sev.p) \\
\hline P7 & Remetea Mare & 0 & 1.14 (S. p.) & 2.14(M.p.) & 0 & 3.28 (M.p) \\
\hline P8 & Dumbravita & 0 & 1.26 (S. p.) & 2.32(M.p.) & 0 & 3.57 (M.p) \\
\hline P9 & Lugoj & 0.22 & 1.08 (S. p.) & 2.98(M.p.) & 0 & 4.29 (Sev.p) \\
\hline P10 & Comlosu Mare & 0 & 0.89 & 0 & 0 & 0.89 \\
\hline P11 & Cenad & 0.34 & 1.58 (S. p.) & 1.98 (S. p.) & 5.94 (Sev.p) & 9.83 (V.Sev.p) \\
\hline P12 & Dudestii Vechi & 0 & 1.40 (S. p.) & 0 & 0 & 1.40 (S. p) \\
\hline P13 & Sannicolau Mare & 0 & 1.16 (S. p.) & 2.30(M.p.) & 5.92 (Sev.p) & 9.38 (V. Sev.p) \\
\hline P14 & Dudestii Noi & 0 & 0.96 & 2.36(M.p.) & 0 & 3.32 (M.p) \\
\hline P15 & Uihei & 0 & 0.80 & 0 & 0 & 0.80 \\
\hline P16 & Satchinez & 0 & 0.95 & 1.77 (S. p.) & 0 & 2.72 (M.p) \\
\hline P17 & Sanpetru Mare & 0.26 & 1.57 (S. p.) & 3.08(M.p.) & 0 & 4.91 Sev.p) \\
\hline P18 & Livezile & 0 & 0.99 & 1.86 (S. p.) & 0 & 2.85 (M.p) \\
\hline Ref. value A [9] & & 50 & 50 & 15 & 10 & \\
\hline
\end{tabular}

\section{Conclusions}

A set of measurements regarding the metal contents in soil in Timis county is presented. Comparison with normal concentrations established by law is made and the contamination/pollution index is computed for $\mathrm{Pb}, \mathrm{Zn}, \mathrm{Cu}$ and $\mathrm{Ni}$ for each sample. The locations with minimal metal concentrations are Comlosu Mare and Uihei, both having brown sandy soils. The locations with the maximal metal concentrations are Ghiroda and Dumbravita, and the locations with the largest multiple pollution index are Cenad and Sannicolau Mare.

\section{References}

[1] T.W. Lane, F.M. Morel, Proc Natl Acad Sci U S A, 97(9) (2000) 4627-4631

[2] „Mediul, sănătatea şi calitatea vieţii”, in Raport anual privind Starea Factorilor de Mediu in Regiunea Vest pe anul 2011, http://arpmtm.anpm.ro/upload/77256_Raportanual\%20privind\%20starea\%20factorilor \%20de\%20mediu\%20in\%20Regiunea\%20VEST\%20in\%202011.pdf, accesed Jan. 2012 
[3] J. Chronopoulos, C. Haidouti, A. Chronopoulou, I. Massas, Sci Total Environ.196 (1997) $91-8$

[4] F. Damian, Gh. Damian, R. Lăcătuşu, Gh. Macovei, Gh.Iepure, I.Năprădean, R.Chira, L. Kollar, L. Raţă and D.C. Zaharia, Carpth. J. of Earth and Environmental Sciences 3 (1), (2008) $85-98$

[5] R. Lacatusu, A.R. Lacatusu, M. Lungu and I.G.Breaban, Carpth. J. of Earth and Environmental Sciences 3 (1), (2008) 75 - 83

[6] Reena Singh, Neetu Gautam, Anurag Mishra, and Rajiv Gupta, Indian J Pharmacol. 43 (3), (2011) 246-253

[7] R. Lăcătuşu and A.R. Lăcătuşu, Carpth. J. of Earth and Environmental Sciences 3 (2), (2008) 115-129

[8] ORDIN nr. 756 din 3 noiembrie 1997 pentru aprobarea Reglementarii privind evaluarea poluarii mediului

[9] R. Lăcătuşu, "Appraising levels of soil contamination and pollution with heavy metals", in Land Information Systems, Developments for planning the sustainable use of land resources, European Soil Bureau, EUR 17729 EN, (1998) 393-402 